\title{
ANALYTICA CHIMICA

\section{Capillary electrochromatographic separation of metal ion species with on-line detection by inductively coupled plasma mass spectrometry}

\author{
Wei-Hsi Chen, Shu-Yu Lin, Chuen-Ying Liu* \\ Department of Chemistry, National Taiwan University, Taipei, Taiwan
}

Received 23 August 1999; received in revised form 4 January 2000; accepted 10 January 2000

\begin{abstract}
A bonded phase capillary column containing macrocyclic polyamine, [28]ane- $\mathrm{N}_{6} \mathrm{O}_{2}$ functional groups was used for the electrophoretic separation of arsenic, chromium and selenium species. A simple device interfacing this capillary electrochromatography (CEC) systems to an inductively coupled plasma mass spectrometer (ICPMS) is described. The dimension of the capillary column was $160 \mathrm{~cm} \times 100 \mu \mathrm{m}$ i.d. To accommodate this electrophoretic separation, an auxiliary capillary was used with nitric acid $(0.05 \mathrm{M})$ as makeup liquid. With the electrokinetic method at $-20 \mathrm{kV}, 20 \mathrm{~s}$ and a nebulizer gas flow rate of $11 \mathrm{~min}^{-1}$, the sample injected was analyzed with an applied potential of $-20 \mathrm{kV}$. The background electrolyte buffer for the separation of $\mathrm{CrO}_{4}{ }^{2-}-\mathrm{Cr}^{3+}$ was phosphate $(20 \mathrm{mM}, \mathrm{pH} 6.5)$. That for $\mathrm{HAsO}_{4}{ }^{2-}-\mathrm{Ph}_{4} \mathrm{As}^{+}$was pyromellitate $(20 \mathrm{mM}$, $\mathrm{pH}$ 6.0) and for $\mathrm{SeO}_{4}{ }^{2-}-\mathrm{SeO}_{3}{ }^{2-}$ was acetate $(20 \mathrm{mM}, \mathrm{pH}$ 6.0). The role of the buffer's anion was also discussed. The separation efficiency of the bonded phase was compared with the bare fused silica. Concentration detection limits for these metal ions were in the low ppb range. In addition, the matrix effect of the established system with the bonded phase was found smaller than that with the bare fused silica. (C) 2000 Elsevier Science B.V. All rights reserved.
\end{abstract}

Keywords: Bonded phase; Capillary electrochromatography; Inductively coupled plasma mass spectrometry; On-line detection; Speciation; Arsenic; Chromium; Selenium

\section{Introduction}

Capillary electrochromatography (CEC) is a newly emerging technique, interest in which becomes evident by the growing number of symposia and meetings devoted to various aspects of the subject. CEC can be divided into two basic categories: packed columns and open tubular columns [1]. In packed columns, a stationary phase is chemically bonded to a support particle that is then packed into a fused silica tube of dimensions similar to those used in CE. However,

\footnotetext{
* Corresponding author. Fax: +886-2-2363-8543.

E-mail address: cyliu@ccms.ntu.edu.tw (C.-Y. Liu)
}

there are some fundamental problems in using packed columns. The first is the difficult fabrication of the frits used to hold the packing materials in place. The other problem involves the formation of bubbles during the electrochromatographic run. An alternate approach to CEC has been developed in order to overcome the problems. The simplest solution would be to bond the appropriate moiety to the wall of the capillary and utilize solute/bonded phase interactions in a manner similar to open tubular GC.

Improvements in column technology will be of prime importance for the continued growth and development of CEC. Bonded phase capillary column containing macrocyclic polyamine have been pre- 
pared and evaluated for their use in the electrophoretic separation of organic and inorganic anions [2-4]. We found that the highly selective property can be attributed to anion complexation, anion exchange and reversal of the electroosmotic flow (EOF) provided by the wall-bonded functional groups.

The development of highly sensitive and selective detectors has also been one of the most important and challenging prerequisites for the growth of CEC. Some of the most sensitive and selective techniques for the determination of metals include microwave-induced plasma atomic emission spectrometry (MIPAES), inductively coupled plasma atomic emission spectrometry (ICPAES), and inductively coupled plasma mass spectrometry (ICPMS). These detection techniques have been successively combined with gas chromatography, liquid chromatography and supercritical fluid chromatography. However, relatively few studies have been published on the use of ICPMS as a means of detection in CE/CEC separations.

Several works have been reported on arsenic speciation by HPLC-ICPMS. The separation of arsenic species is mainly made with ion exchange [5-7] and ion-pairing reversed-phase $[8,9]$ techniques. For the speciation of selenium, reversed-phase $[10,11]$, ion exchange [12,13] and size exclusion [14] separation have been studied. Only a few works describe the simultaneous separation of arsenic and selenium species [15], as well as on-line hyphenation of CE with ICPMS for the determination of As and Se speciation [16,17].

For the on-line ICPMS detection the analytes separated by $\mathrm{CE} / \mathrm{CEC}$, the design of a suitable interface is necessary because of the very small quantities of sample injected and the very low EOF rates $\left(<1 \mu 1 \mathrm{~min}^{-1}\right)$ through the capillary. Several nebulizers have been used effectively as interfaces for CE with ICPMS detection, including the Meinhard concentric nebulizer [18-21], the microconcentric nebulizer [22], the direct injection nebulizer [23], the ultrasonic nebulizer [24], the high efficiency nebulizer [25] and the oscillating capillary nebulizer [26]. In almost all the CE-ICPMS experiments described to date [19-25], a conducting makeup buffer flowing concentrically around the CE capillary exit is used to complete the necessary ground connection as well as to supplement the low EOF in order to achieve stable nebulizer operation. In this report, a simple interface similar to that developed by Mei et al. [8] but employing a cross-flow nebulizer coupled with either bonded phase or bare fused silica for the on-line detection of different species of chromium, arsenic and selenium was investigated.

\section{Experimental}

\subsection{Apparatus}

\subsubsection{Inductively coupled plasma mass spectrometry (ICPMS)}

An ICPMS (Elan 6000, Perkin-Elmer, Norwalk, CT, USA) with cross-flow nebulizer, Scott-type Ryton double pass spray chamber and quadrupole mass analyzer was interfaced to the CEC capillary. The operating parameters for ICPMS listed in Table 1 were used except where indicated. The radio-frequency power was set at $1200 \mathrm{~W}$. Plasma gas, intermediate gas and nebulizer gas flows were $15,1.2$ and $1.01 \mathrm{~min}^{-1}$, respectively. The following isotopes: ${ }^{75} \mathrm{As},{ }^{82} \mathrm{Se},{ }^{52} \mathrm{Cr}$ and ${ }^{53} \mathrm{Cr}$ were monitored for analysis.

\subsubsection{Capillary electrochromatography}

Fused silica capillary columns (Restek, Bellefonte, PA, USA) with an i.d. of $100 \mu \mathrm{m}$ and an o.d. of $375 \mu \mathrm{m}$ were used. The bonded phase capillary column was $160 \mathrm{~cm}$ long. A high voltage dc power supply (Model PS/EH40R02.5, Glassman, NJ, USA) provided a voltage of up to $40 \mathrm{kV}$ between the ends of the capillary. The inlet end of the capillary was held at a negative potential while the outlet end was grounded. A platinum wire $(0.5 \mathrm{~mm}$ diameter, $5 \mathrm{~cm}$ long) was used as the electrode in the supply electrolyte reservoir. Electrophoretic currents were measured using a home-made microammeter. The auxiliary capillary tubes were of $150 \mu \mathrm{m}$ i.d. and the total length was

Table 1

ICPMS operating conditions

\begin{tabular}{ll}
\hline Radio-frequency power $(\mathrm{W})$ & 1200 \\
Plasma gas flow rate $\left(1 \mathrm{~min}^{-1}\right)$ & 15 \\
Intermediate gas flow rate $\left(1 \mathrm{~min}^{-1}\right)$ & 1.2 \\
Nebulizer gas flow rate $\left(1 \mathrm{~min}^{-1}\right)$ & 1.0 \\
Sample cone $(\mathrm{mm})$ & $\mathrm{Ni}, 1.1$ \\
Skimmer cone $(\mathrm{mm})$ & $\mathrm{Ni}, 0.9$ \\
Dwell time per mass $(\mathrm{ms})$ & 100 \\
Nebulizer & Cross-flow pneumatic \\
Spray chamber & Scott type ${ }^{82} \mathrm{Cr},{ }^{53} \mathrm{Cr}$ \\
Isotopes monitored & ${ }^{75} \mathrm{As},{ }^{82} \mathrm{Se},{ }^{52}$ \\
\hline
\end{tabular}


$50 \mathrm{~cm}$. For the bonded phase, samples were injected from the negative end by electrokinetic mode $(-20 \mathrm{kV}$, $20 \mathrm{~s}$ ) with nebulizer gas flow of $11 \mathrm{~min}^{-1}$. For the bare fused silica, samples were injected in a similar manner but from the positive end.

\subsubsection{CEC-ICPMS interface}

The nebulizer-capillary connection is shown in Fig. 1. To accommodate a CEC capillary and a makeup buffer flow for the ground connection, we used two fused silica tubes. The tubes were connected by means of $\mathrm{Y}$ union tube made from quartz (Marietta, Ohio Valley) to the argon nebulizer. This Y union was appropriate for fused silica tubing having outside diameters from 0.18 to $0.53 \mathrm{~mm}$. The fused silica tubes were securely mounted by using GC injection rubber plug (Shimadzu, Japan). Nitric acid (0.05 M) as the makeup buffer was used to tune the ICP for maximum signal response when the electrophoretic separation was carried out.

\subsubsection{Flow rate of electrophoretic separation}

At first, density of a background electrolyte (phosphate buffer, $50 \mathrm{mM}, \mathrm{pH} 7.0$ ) and the make up liquid (nitric acid, $0.05 \mathrm{M}$ ) were measured, respectively. After both capillary columns were filled with the liquid (Fig. 1) and at $11 \mathrm{~min}^{-1}$ of the nebulizer gas flow, the weights consumed per min from the electrophoresis and auxiliary capillaries were measured at the successive time of 15, 30, 60 and $90 \mathrm{~min}$. Liquid flow rate was estimated by converting the weight to volume consumed.

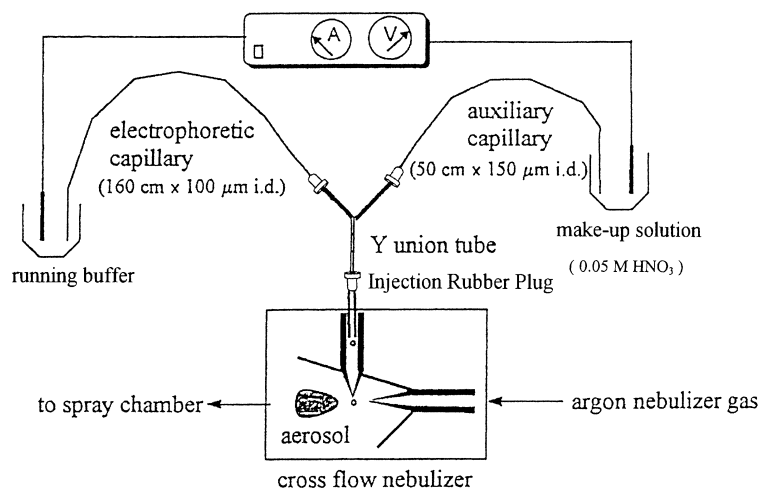

Fig. 1. The interface for coupling capillary electrochromatography and inductively coupled plasma mass spectrometer.

\subsection{Reagents and chemicals}

Most chemicals were of analytical reagent grade from Merck (Darmstadt, Germany). Purified water $(18 \mathrm{M} \Omega \mathrm{cm})$ from a Milli-Q water purification system (Millipore, Bedford, MA, USA) was used to prepare all solutions. $\gamma$-Glycidoxypropyltrimethoxysilane was obtained from Aldrich (Milwaukee, WI, USA). All liquid reagents and solvents used in moisture-sensitive reactions were distilled and collected over type $4 \AA$ molecular sieves. Anion standards from reagent-grade sodium selenate, sodium selenite, sodium arsenate, sodium arsenite, dimethylarsinic acid, phenylarsonic acid, chromium nitrate, and sodium chromate were purchased from Merck. Cation standards were prepared from tetraphenylarsonium chloride (Wako, Japan). Stock solutions (0.01 M) of both cations and anions were prepared in pure water and diluted appropriately prior to use. Phenylarsine oxide (TCI, Japan) as neutral standard was prepared in methanol and diluted to the desired concentration using pure water, whenever required. All solvents and solutions for CEC analysis were filtered through a $0.45 \mu \mathrm{m}$ PTFE membrane (Millipore).

\subsection{Synthesis of}

1,15-dioxa-4,8,12,18,22,26-hexaazacyclooctaeicosane ([28]ane $-\mathrm{N}_{6} \mathrm{O}_{2}$ )

The anion complexone was prepared from 3,3'-diaminodipropylamine and triethylamine, according to the methods described by Liu et al. [3].

\subsection{Coating of capillaries with $\gamma$-glycidoxypropyltrimethoxysilane [3]}

Fused silica capillaries were first flushed with $1 \mathrm{M} \mathrm{NaOH}(30 \mathrm{~min})$, then pure water $(15 \mathrm{~min})$, $1 \mathrm{M} \mathrm{HCl}(30 \mathrm{~min})$ and pure water $(15 \mathrm{~min})$. The capillaries were purged with nitrogen for $20 \mathrm{~min}$, then dried at $110^{\circ} \mathrm{C}$ overnight. For coating, the capillary was filled with a $10 \%(\mathrm{w} / \mathrm{v})$ solution of $\gamma$-glycidoxypropyltrimethoxysilane in toluene. The capillary was kept for $3 \mathrm{~h}$ at $110^{\circ} \mathrm{C}$ for silylization. After purging with toluene to remove unreacted reagent for several minutes, the capillaries were dried in a vacuum oven. The capillary was then filled with 
a $1 \%(\mathrm{w} / \mathrm{v})$ solution of the macrocyclic compound, [28] ane- $\mathrm{N}_{6} \mathrm{O}_{2} 6 \mathrm{HCl}$ in DMF. After standing for $10 \mathrm{~h}$ at $120^{\circ} \mathrm{C}$ for functionalization, the dried capillaries were purged with methanol and pure water for several minutes before equilibration with buffer solution. They were then ready for use.

\section{Results and discussion}

In this work, CEC coupling with ICPMS as a means to determine the speciation of $\mathrm{As}$, Se and $\mathrm{Cr}$ was studied. Selenium has six isotopes, ${ }^{74} \mathrm{Se}$ $(0.89 \%),{ }^{76} \mathrm{Se}(9.36 \%),{ }^{77} \mathrm{Se}(7.63 \%),{ }^{78} \mathrm{Se}(23.4 \%)$, ${ }^{80} \mathrm{Se}(49.6 \%)$ and ${ }^{82} \mathrm{Se}(8.73 \%)$ that can potentially be used to monitor selenium. Three isotopes, ${ }^{80} \mathrm{Se},{ }^{78} \mathrm{Se}$ and ${ }^{76} \mathrm{Se}$, are immediately eliminated because their peaks overlap those of the argon dimers $\left({ }^{40} \mathrm{Ar}^{40} \mathrm{Ar},{ }^{40} \mathrm{Ar}^{38} \mathrm{Ar},{ }^{40} \mathrm{Ar}^{36} \mathrm{Ar}\right)$, which are highly abundant in the plasma. Of the three remaining selenium isotopes, ${ }^{82} \mathrm{Se}$ is the best choice because of its higher abundance and the isobaric interference from ${ }^{82} \mathrm{Kr}$ is small and easily correctable [27]. ${ }^{75} \mathrm{As}$ is a unique isotope. ${ }^{52} \mathrm{Cr}(83.8 \%)$ and ${ }^{53} \mathrm{Cr}(9.5 \%)$ exist in the nature. The interference of polyatomic ions in ICPMS analysis is ${ }^{40} \mathrm{Ar}^{12} \mathrm{C}^{+}$and ${ }^{40} \mathrm{Ar}^{13} \mathrm{C}^{+}$. Although the sensitivity of ${ }^{52} \mathrm{Cr}$ is nine times better than ${ }^{53} \mathrm{Cr}$, the interference of ${ }^{52} \mathrm{Cr}$ from $\mathrm{ArC}^{+}$is 90 times greater than that of ${ }^{53} \mathrm{Cr}$. Therefore, both ${ }^{52} \mathrm{Cr}$ and ${ }^{53} \mathrm{Cr}$ were measured for this study.

\subsection{Liquid flow rate and nebulizer gas flow rate}

ICPMS detector for CEC require that the sample be physically transported from the capillary to the ionization source, in contrast to on-capillary detectors, such as UV-VIS absorbance or fluorescence. Besides, the buffer/analyte solutions of electrophoresis would stagnate on leaving the electric field of the electrophoretic capillary, so the placing of the ground electrode is a problem for the CEC-ICPMS coupling system. The other problem is that the rapidly flowing gas that exits through the nebulizer produces a suction that tends to induce laminar flow in the electrophoresis capillary. Laminar flow is normally considered to be undesirable in electrophoretic study. To overcome this problem, electrolyte sheath has been used to make an electric connection to the outlet of the capillary in in- terfaces to ICPMS [6]. Kinzer et al. reported that the magnitude and direction of laminar flow could be selected by proper adjustment of the sheath flow rate in a concentric nebulizer $(\mathrm{CCN})$ interface [28]. In $\mathrm{CCN}$, the sample solution passes through a capillary surrounded by a high-velocity argon gas stream parallel to the capillary axis. While cross-flow nebulizer has a liquid-carrying capillary set at a right angle to the tube carrying the gas stream. Compared to the $\mathrm{CCN}$, a higher gas flow rate was needed and poorer efficiency of nebulization might be. However, with the arrangement shown in Fig. 1, buffer/analyte exit from the electrophoresis capillary carried along with makeup liquid were self-aspirated toward the nebulizer and no need of peristaltic pumping. This is an easier and simpler method than that proposed by Majidi et al. [29].

For decreasing the laminar flow, a makeup liquid was necessary. We use a $160 \mathrm{~cm}$ long electrophoresis capillary having $100 \mu \mathrm{m}$ i.d. and a $50 \mathrm{~cm}$ long auxiliary capillary having $150 \mu \mathrm{m}$ i.d. (Fig. 1). Excessive increase in the nebulizer gas flow rate was accompanied by a decrease in the peak signal and ionization efficiency due to more flow of Ar gas and solvent molecules. Meanwhile this gave rise to a greater laminar flow rate, faster migration velocity and poorer separation efficiency. Decreasing the nebulizer gas flow, a longer electrophoretic separation time was needed. For the electrophoretic separation of $\mathrm{SeO}_{4}{ }^{2-}$ and $\mathrm{AsO}_{4}{ }^{3-}$ with the bonded phase, changes in migration time, peak intensity and resolution with the nebulizer gas flow were investigated. $11 \mathrm{~min}^{-1}$ was found to be the optimum condition (Fig. 2). At the gas flow rate of $11 \mathrm{~min}^{-1}$ and no applied voltage, the liquid flows from the makeup buffer and the bonded phase tubing for three measurements are 13.4 \pm 0.1 and $1.03 \pm 0.1 \mu 1 \mathrm{~min}^{-1}$, respectively. When voltage was applied $(-15 \mathrm{kV})$, the liquid flows from makeup buffer and bonded phase tubing are $13.2 \pm 0.1$ and $1.11 \pm 0.08 \mu 1 \mathrm{~min}^{-1}$, respectively.

\subsection{Electroosmotic flow (EOF)}

With nebulizer gas flow, the sum of the ion velocity in the electrophoresis capillary is due to EOF, electrophoretic migration, and the laminar flow. The EOF of the bonded phase was determined with phenylarsine oxide as neutral marker. Without applied voltage, the migration of the neutral marker is purely due to 


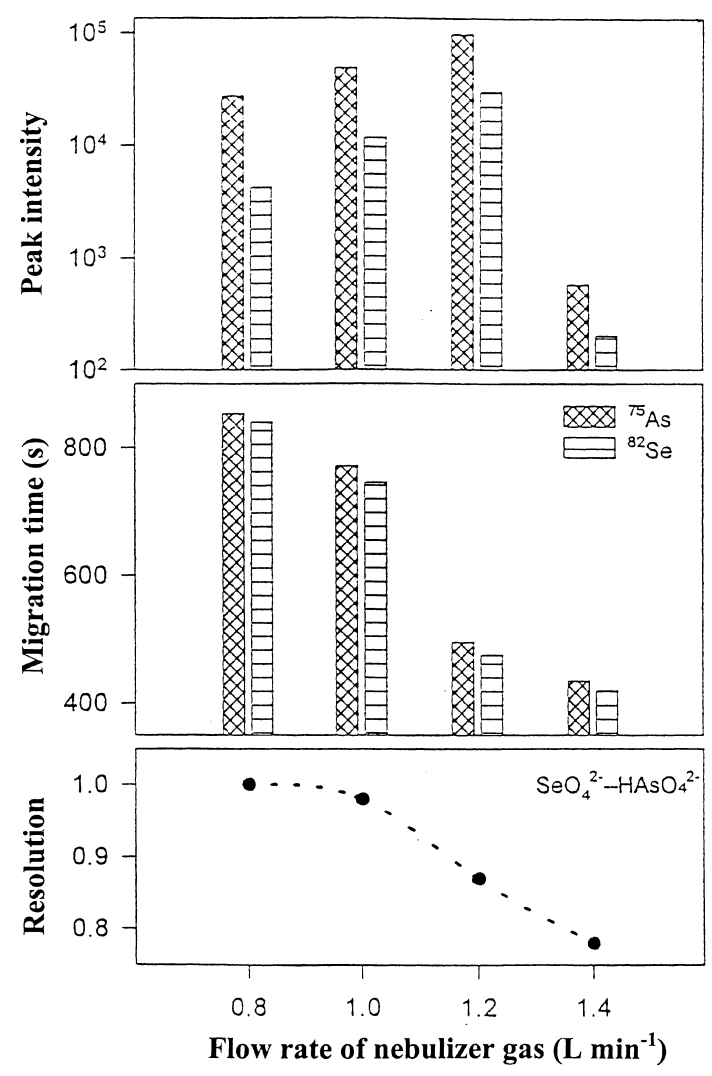

Fig. 2. Effect of nebulizer gas flow rate on the peak intensity, migration time and resolution for the electrophoretic separation of $\mathrm{AsO}_{4}{ }^{3-}$ and $\mathrm{SeO}_{4}{ }^{2-}$ with ICPMS on-line detection. Capillary column: [28] ane- $\mathrm{N}_{6} \mathrm{O}_{2}$ bonded phase; dimension is $160 \mathrm{~cm} \times 100 \mu \mathrm{m}$ i.d. Sample concentration: $1 \mu \mathrm{g} \mathrm{ml}^{-1}$ for each. Sample injection: electrokinetic method $(-20 \mathrm{kV}, 20 \mathrm{~s})$ with nebulizer gas flow off. Background electrolyte: phosphate buffer (50 mM, pH 6.4). Applied voltage: $-20 \mathrm{kV}$.

the laminar flow (Fig. 3A). When the voltage is applied $(-15 \mathrm{kV})$, the migration is due to the EOF and the laminar flow (Fig. 3B). The results show that the latter condition accelerates the migration of the analyte (around $92 \mathrm{~s}$ ) and narrows the solute band. In this case, the $\mu_{\text {EOF }}$ is $-2.88 \times 10^{-4} \mathrm{~cm}^{2} \mathrm{~V}^{-1} \mathrm{~s}^{-1}$ toward the positive end, and the linear velocity increased is $0.27 \mathrm{~mm} \mathrm{~s}^{-1}$. While the bare fused silica at an applied potential of +20 and $-20 \mathrm{kV}$ was used instead, the migration time was 399 and $581 \mathrm{~s}$, respectively. The increased linear velocity is $1.27 \mathrm{~mm} \mathrm{~s}^{-1}$ which is just twice the EOF velocity. Therefore, $\mu_{\mathrm{EOF}}$ was $+5.06 \times 10^{-4} \mathrm{~cm}^{2} \mathrm{~V}^{-1} \mathrm{~s}^{-1}$ toward the negative end. The slower migration of the neutral marker and differ-

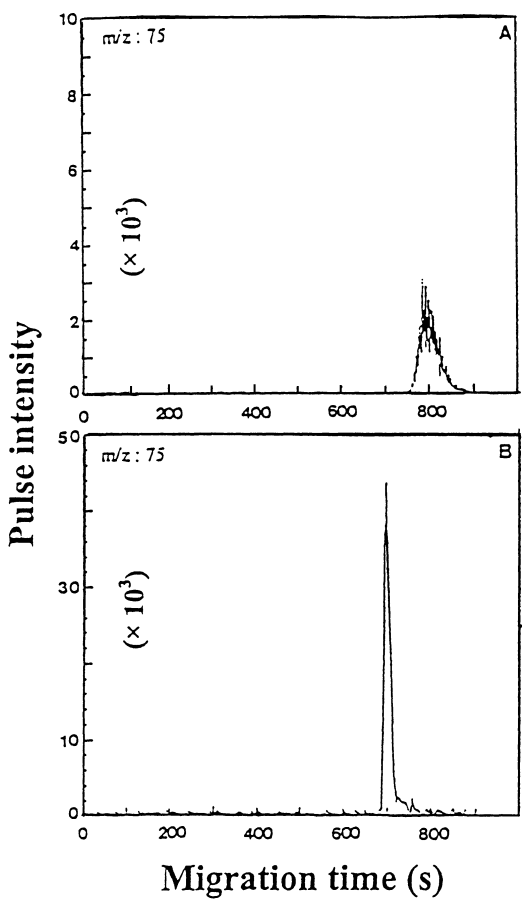

Fig. 3. Electropherograms of neutral marker, phenylarsine oxide, in the CEC-ICPMS coupled system. Capillary column: [28]ane- $\mathrm{N}_{6} \mathrm{O}_{2}$ bonded phase; dimension is $160 \mathrm{~cm} \times 100 \mu \mathrm{m}$ i.d. Background electrolyte: phosphate buffer (20 mM, pH 6.5). Sample concentration: $1 \mu \mathrm{g} \mathrm{ml}^{-1}$. Sample injection: (A) without applied voltage; (B) applied voltage of $-15 \mathrm{kV}, 10 \mathrm{~s}$. Applied voltage for the separation: $-15 \mathrm{kV}$.

ent EOF direction in the bonded phase compared to that of the bare fused silica demonstrated some chemical interaction might occur in the bonded phase.

\subsection{Optimization of the separation conditions}

Using bonded phase $(90 \mathrm{~cm}, 100 \mu \mathrm{m}$ i.d.), pyromellitate buffer $(25 \mathrm{mM}, \mathrm{pH} 6.0)$ and electrokinetic injection $(+20 \mathrm{kV}, 20 \mathrm{~s})$ with nebulizer gas flow off, no peak was found within $15 \mathrm{~min}$ at an applied potential of $+20 \mathrm{kV}$ for the separation of the arsenate and selenite mixture. Moreover, at the given condition but sample injection from the negative end, coelution of arsenate and selenite was found at the migration time of $405 \mathrm{~s}$ with the applied potential of $-20 \mathrm{kV}$. Therefore, negative end injection was adopted for the bonded phase. In this way, the electrophoretic migration of the solute, EOF and the laminar flow are all toward the detector. 

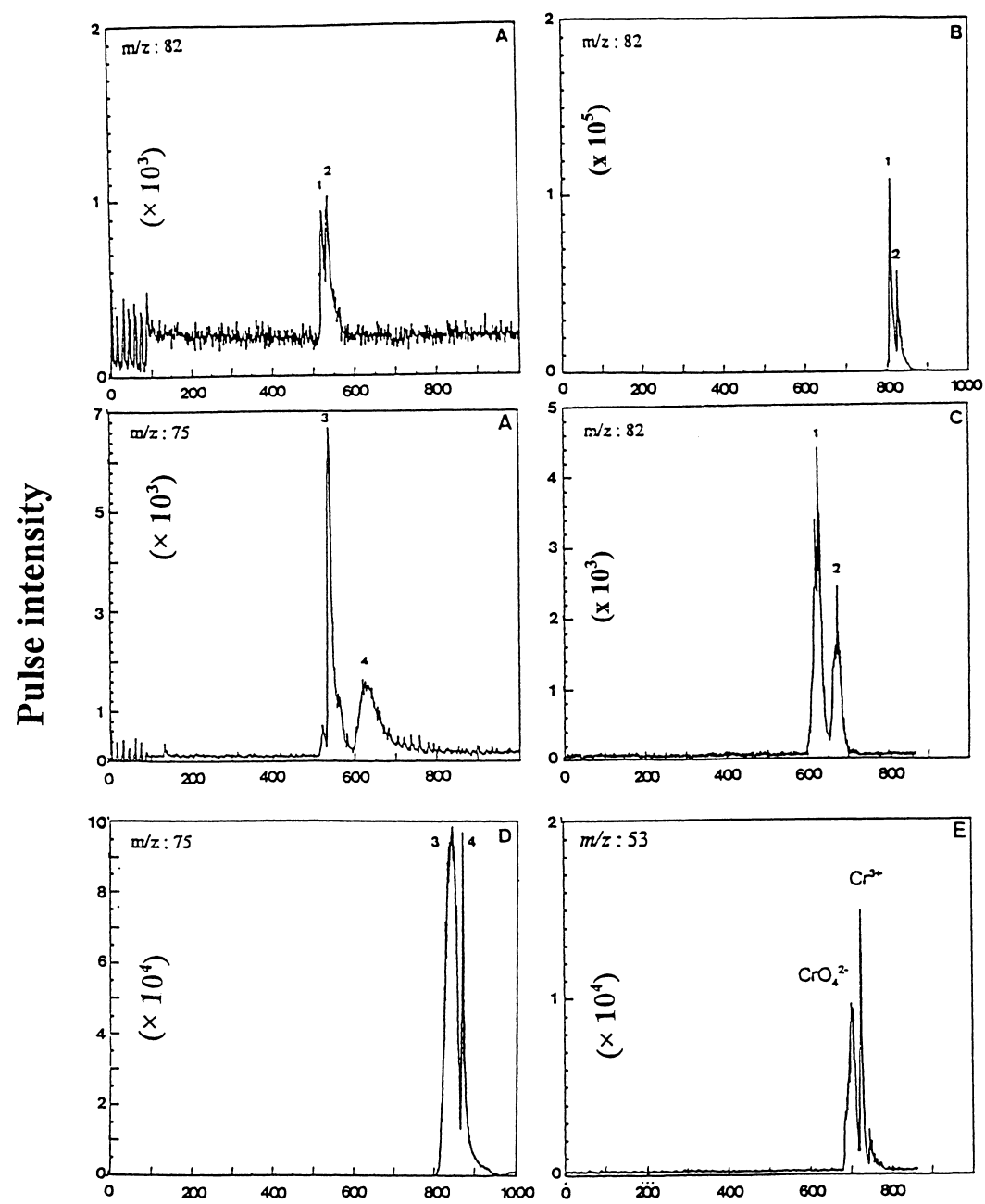

Migration time (s)

Fig. 4. Electropherogram for the separation of arsenic and selenium species. Capillary column: [28]ane- $\mathrm{N}_{6} \mathrm{O}_{2}$ bonded phase; dimension is $160 \mathrm{~cm} \times 100 \mu \mathrm{m}$ i.d. Sample concentration: $1 \mu \mathrm{g} \mathrm{ml}^{-1}$ for each, but $0.2 \mu \mathrm{g} \mathrm{ml}^{-1}$ for chromium species. Sample injection: electrokinetic method $(-20 \mathrm{kV}, 20 \mathrm{~s})$ with the nebulizer gas flow at $11 \mathrm{~min}^{-1}$, except (A) without nebulizer gas flow. Separation voltage: $-20 \mathrm{kV}$. Background electrolyte: (A) phosphate $(50 \mathrm{mM}, \mathrm{pH} 6.3)$; (B) $o$-phthalate $(20 \mathrm{mM}, \mathrm{pH} 6.2)$; (C) acetate $(20 \mathrm{mM}, \mathrm{pH} 6.0)$; (D) pyromellitate (25 mM, pH 6.0); (E) phosphate (20 mM, pH 6.5). Peak identification: $1, \mathrm{SeO}_{4}{ }^{2-} ; 2, \mathrm{SeO}_{3}{ }^{2-} ; 3, \mathrm{HAsO}_{4}{ }^{2-} ; 4,(\mathrm{Ph})_{4} \mathrm{As}^{+}$.

\subsubsection{Sample injection}

For the separation of selenium and arsenic species with the bonded phase and pyromellitate buffer ( $25 \mathrm{mM}, \mathrm{pH} 6.0$ ) at an applied voltage of $-20 \mathrm{kV}$, sample introduction was varied using electrokinetic method $(-20 \mathrm{kV}, 20 \mathrm{~s})$ with nebulizer gas flow off, or with nebulizer gas flow at $11 \mathrm{~min}^{-1}$ and hydrodynamic method only with nebulizer gas flow at
$11 \mathrm{~min}^{-1}$. The separation efficiency indicated that the hydrodynamic method was worse than the electrokinetic method, and electrokinetic method with nebulizer gas flow kept at $11 \mathrm{~min}^{-1}$ was better than that with nebulizer gas flow off. But in the latter condition, there is an unexplainable zig-zag base line shown in the first $100 \mathrm{~s}$ of the migration time (Fig. 4A). 
Table 2

Chemical and physical properties of the model compounds

\begin{tabular}{|c|c|c|c|c|c|c|}
\hline Compound & $M_{\mathrm{r}}$ & $\mathrm{p} K_{\mathrm{a}}\left(25^{\circ} \mathrm{C}, \mu=0\right)^{\mathrm{a}}$ & Radius ( & Effective charge (pH 6.2) & Equivalent conductance & Migration time (min) \\
\hline Chloride & 35.5 & & 1.81 & 1 & 76.35 & \\
\hline Selenate & 143 & $-3 ; 1.66$ & 2.35 & 2 & 75.7 & $625^{\mathrm{b}} ; 810^{\mathrm{c}}$ \\
\hline Selenite & 127 & $2.64 ; 8.27$ & 2.25 & 1.008 & & $672^{\mathrm{b}} ; 830^{\mathrm{c}}$ \\
\hline Arsenate & 139 & $2.25 ; 6.77 ; 11.60$ & & 1.212 & 34 & $550^{\mathrm{d}} ; 840^{\mathrm{e}}$ \\
\hline Arsenite & 124 & 9.23 & & 0.001 & & \\
\hline$(\mathrm{Ph})_{4} \mathrm{As}^{+}$ & 383 & & & 1 & & $630^{\mathrm{d}} ; 866^{\mathrm{e}}$ \\
\hline Chromate & 116 & $-0.2 ; 6.51$ & 2.42 & 1.328 & 85 & \\
\hline $\mathrm{Cr}^{3+}$ (aquo) & 52 & 4.0 & & 2.007 & & \\
\hline Phosphate & 95 & $2.15 ; 7.20 ; 12.38$ & & 1.091 & $33 ; 57 ; 69$ & \\
\hline Acetate & 59 & 4.75 & & 0.966 & 40.9 & \\
\hline Pyromellitate & 254 & $1.70 ; 3.12 ; 4.92 ; 6.23$ & & 3.444 & 68.1 & \\
\hline Phthalate & 166 & $2.95 ; 5.40$ & & 1.863 & 52.3 & \\
\hline
\end{tabular}

${ }^{\mathrm{a}} \mathrm{p} K_{\mathrm{a}}$, Radius and Limiting equivalent ionic conductance ( $\mathrm{sm}^{2} /$ equivalent): data from [30,31].

${ }^{\mathrm{b}}$ Acetate buffer.

${ }^{\mathrm{c}}$ Phthalate buffer.

${ }^{\mathrm{d}}$ Phosphate buffer.

e Pyromellitate buffer.

\subsubsection{Applied potential}

For the separation of $\mathrm{SeO}_{4}{ }^{2-}, \mathrm{SeO}_{3}{ }^{2-}, \mathrm{HAsO}_{4}{ }^{2-}$ and $(\mathrm{Ph})_{4} \mathrm{As}^{+}$mixture, it was found that increasing the applied voltage from $0,-10,-15,-20$ and $-25 \mathrm{kV}$, a better resolution and higher intensity was obtained. Meanwhile faster mobility was indicated, except for the positive ion, $(\mathrm{Ph})_{4} \mathrm{As}^{+}$.

\subsubsection{Nature of the electrolyte buffer}

The interaction between analyte and the bonded phase was expected to be predominantly anion complexation $[3,4]$. Taking account of having higher fraction of protonated bonded phase and higher effective charge of the analyte, $\mathrm{pH}$ value of the background electrolyte was kept at 6.0-6.5. Here, the role of buffer's anion was also considered. A series of buffers with different radius, effective charge and equivalent conductance (Table 2) were studied to see what effect the anion would have on the separation.

Using phosphate buffer (50 mM, pH 6.3), applied potential of $-20 \mathrm{kV}$, electrokinetic injection $(20 \mathrm{~s}$, $-20 \mathrm{kV}$ ) and nebulizer gas flow off, the separation of $\mathrm{SeO}_{4}{ }^{2-}, \mathrm{SeO}_{3}{ }^{2-}, \mathrm{HAsO}_{4}{ }^{2-}$ and $(\mathrm{Ph})_{4} \mathrm{As}^{+}$is shown in Fig. 4A. Resolution $\left(R_{\mathrm{S}}\right)$ for the $\mathrm{SeO}_{4}{ }^{2-}$ and $\mathrm{SeO}_{3}{ }^{2-}$ is 0.62 , while that for a $\mathrm{HAsO}_{4}{ }^{2-}$ and $(\mathrm{Ph})_{4} \mathrm{As}^{+}$ mixture is 1.29. A lower concentration of phosphate buffer $(20 \mathrm{mM}, \mathrm{pH}$ 6.2) was further tested in order to separate more binary mixture, $\mathrm{HAsO}_{4}{ }^{2-}-\mathrm{AsO}_{2}{ }^{-}$,
$\mathrm{HAsO}_{4}{ }^{2-}-(\mathrm{Ph}) \mathrm{AsO}_{3}{ }^{-}, \quad \mathrm{HAsO}_{4}{ }^{2-}-(\mathrm{Ph}) \mathrm{AsO}$ and $\mathrm{HAsO}_{4}{ }^{2-}-(\mathrm{Me})_{2} \mathrm{AsO}_{2}{ }^{-}$. However, only the mixture of $\mathrm{HAsO}_{4}{ }^{2-}-(\mathrm{Me})_{2} \mathrm{AsO}_{2}{ }^{-}$demonstrated a better separation efficiency with resolution of 0.81 .

Phthalate buffer $(20 \mathrm{mM}, \mathrm{pH}$ 6.2) was then used. Only the separation of $\mathrm{SeO}_{4}{ }^{2-}$ and $\mathrm{SeO}_{3}{ }^{2-}$ improved significantly but no resolution for the mixture of $\mathrm{HAsO}_{4}{ }^{2-}$ and $(\mathrm{Ph})_{4} \mathrm{As}^{+}$was shown (Fig. 4B). With acetate buffer (20 mM, pH 6.0), a satisfactory resolved selenium species was indicated (Fig. 4C), but not for the arsenic species. Pyromellitate buffer $(25 \mathrm{mM}$, pH 6.0) and sample injected using electrokinetic method and nebulizer gas flow showed a better separation of $\mathrm{HAsO}_{4}{ }^{2-}$ and $(\mathrm{Ph})_{4} \mathrm{As}^{+}$(Fig. 4D).

In conclusion, $\mathrm{SeO}_{4}{ }^{2-}$ and $\mathrm{SeO}_{3}{ }^{2-}$ could be separated efficiently in the acetate and phthalate buffer; while $\mathrm{HAsO}_{4}{ }^{2-}$ and $(\mathrm{Ph})_{4} \mathrm{As}^{+}$could be well separated at the phosphate and pyromellitate buffer. A competitive anion complexation between analytes and the background buffer toward the bonded phase was distinct, since a longer separation time was needed in the buffer having higher effective charge (as shown in Table 2 and Fig. 4). The results also indicated that a greater affinity for phthalate than acetate and pyromellitate than phosphate toward the bonded phase.

At the condition of phosphate buffer $(20 \mathrm{mM}, \mathrm{pH}$ $6.5)$ and an applied potential of $-20 \mathrm{kV}, \mathrm{CrO}_{4}{ }^{2-}$ and $\mathrm{Cr}^{3+}$ could be well separated too (Fig. 4E). 


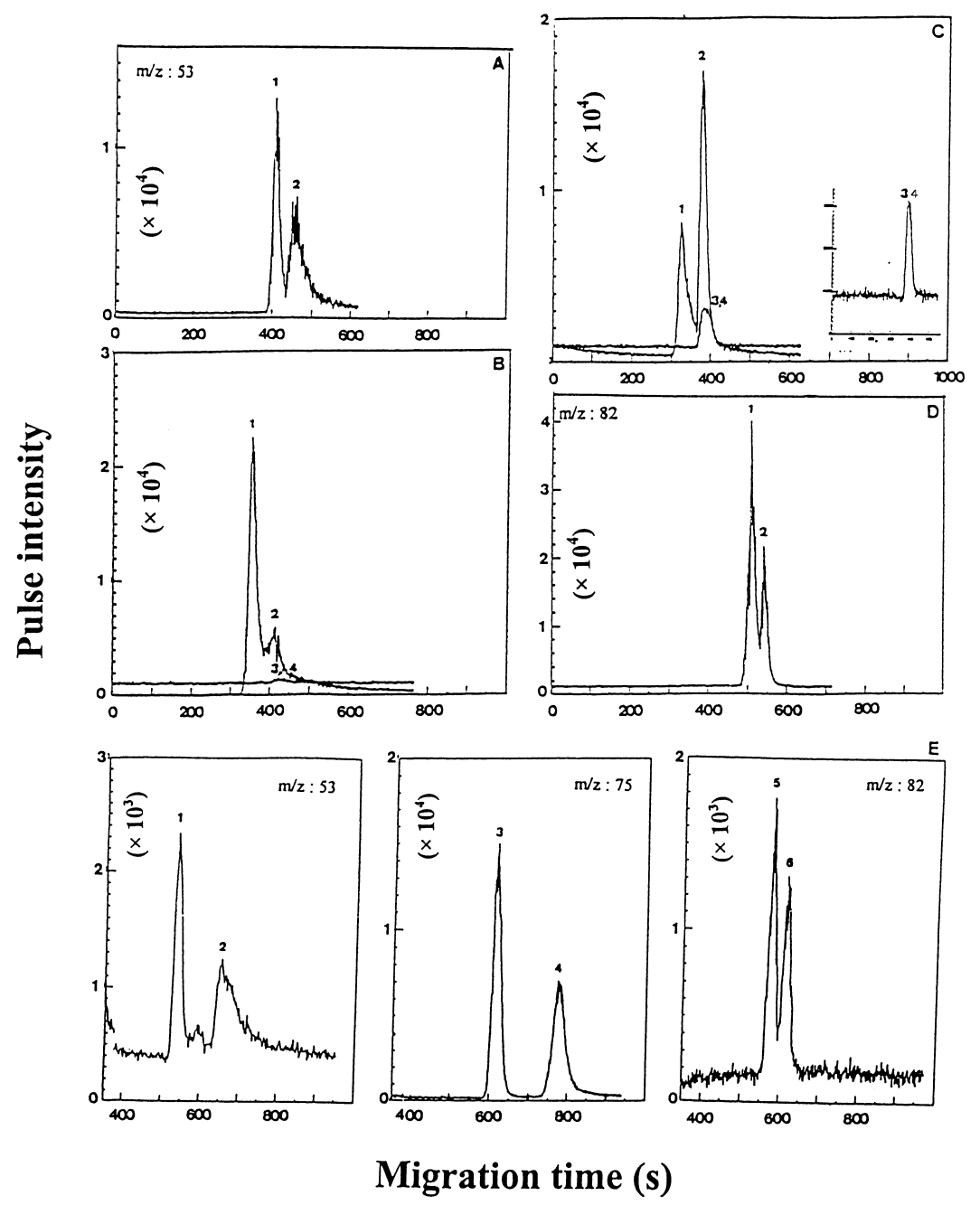

Fig. 5. Electropherograms for the separation of chromium, arsenic and selenium species with bare capillary column. Capillary column: bare fused silica; dimension is $160 \mu \mathrm{m} \times 100 \mu \mathrm{m}$ i.d. Sample concentration: $0.2 \mu \mathrm{g} \mathrm{ml}^{-1}$ for chromium species and $1 \mu \mathrm{g} \mathrm{ml} l^{-1}$ for arsenic and selenium species. Sample injection: (A and B) electrokinetic method $(+20 \mathrm{kV}, 20 \mathrm{~s})$ and nebulizer gas flow kept at $1 \mathrm{ml} \mathrm{min}^{-1}$; (C and E) without applied voltage only with nebulizer gas flow at $1 \mathrm{ml} \mathrm{min}^{-1}$; (D) applied voltage $(-20 \mathrm{kV}, 20 \mathrm{~s})$ and nebulizer gas flow kept at $1 \mathrm{ml} \mathrm{min}^{-1}$. Background electrolyte: phosphate $(20 \mathrm{mM}, \mathrm{pH} 6.2)$. Separation voltage: (A, B and C) $+20 \mathrm{kV}$; (D and E) $-20 \mathrm{kV}$. Peak identification: (A) $1, \mathrm{Cr}^{3+} ; 2, \mathrm{CrO}_{4}{ }^{2-}$. (B and C) $1,(\mathrm{Ph})_{4} \mathrm{As}^{+} ; 2, \mathrm{HAsO}_{4}{ }^{2-} ; 3, \mathrm{SeO}_{3}{ }^{2-} ; 4, \mathrm{SeO}_{4}{ }^{2-}$. (D) $1, \mathrm{SeO}_{4}{ }^{2-} ; 2, \mathrm{SeO}_{3}{ }^{2-}$. (E) 1 , $\mathrm{CrO}_{4}{ }^{2-} ; 2, \mathrm{Cr}^{3+} ; 3, \mathrm{HAsO}_{4}{ }^{2-} ; 4,(\mathrm{Ph})_{4} \mathrm{As}^{+} ; 5, \mathrm{SeO}_{4}{ }^{2-} ; 6, \mathrm{SeO}_{3}{ }^{2-}$.

3.4. Comparison of the separation efficiency of the bonded phase and the bare fused silica capillary column

For a better understanding the separation role of the bonded phase, a bare fused silica capillary column was also used. With the established system, but both sample injection and separation were changed to $+20 \mathrm{kV}$. Cr(III) and $\mathrm{Cr}(\mathrm{VI})$ were well separated (Fig. $5 \mathrm{~A})$. But no selenium species and only $(\mathrm{Ph})_{4} \mathrm{As}^{+}$as well as a small peak of $\mathrm{HAsO}_{4}{ }^{2-}$ were found (Fig. 5B). A counter-migration of the selenium species with the EOF and the laminar flow is obvious, since the surface of the bare fused silica carries the negative charge. 
Table 3

Separation efficiency of metal speciation by CE/CEC-ICPMS with various capillary columns $\mathrm{s}^{\mathrm{a}}$

\begin{tabular}{|c|c|c|c|c|c|c|}
\hline \multirow[t]{2}{*}{ Analyte } & \multicolumn{3}{|c|}{$\left[28\right.$ ]ane- $\mathrm{N}_{6} \mathrm{O}_{2}$ bonded phase ${ }^{\mathrm{b}}$} & \multicolumn{3}{|c|}{ Bare fused silica ${ }^{c}$} \\
\hline & $t_{\mathrm{m}}(\mathrm{s})$ & $N\left(\mathrm{~m}^{-1}\right)$ & $R_{\mathrm{S}}$ & $t_{\mathrm{m}}(\mathrm{s})$ & $N\left(\mathrm{~m}^{-1}\right)$ & $R_{\mathrm{S}}$ \\
\hline $\mathrm{CrO}_{4}{ }^{2-}$ & 707 & 8200 & & 407 & 1300 & \\
\hline $\mathrm{Cr}^{3+}$ & 723 & 33300 & 0.80 & 374 & 2100 & 0.81 \\
\hline $\mathrm{HAsO}_{4}{ }^{2-}$ & 840 & 3600 & & 620 & 1100 & \\
\hline $\mathrm{Ph}_{4} \mathrm{As}^{+}$ & 866 & 47500 & 0.89 & 777 & 1000 & 2.85 \\
\hline $\mathrm{SeO}_{4}{ }^{2-}$ & 625 & 6400 & & 507 & 5900 & \\
\hline $\mathrm{SeO}_{3}{ }^{2-}$ & 672 & 5800 & 1.02 & 538 & 5600 & 0.99 \\
\hline
\end{tabular}

${ }^{a}$ Dimension of the capillary column: $160 \mathrm{~cm} \times 100 \mu \mathrm{m}$ i.d. Abbreviation $-t_{\mathrm{m}}$ : migration time; $R_{\mathrm{s}}$ : resolution; $N$ : No. of theoretical plate. $R_{\mathrm{s}}=2\left(t_{\mathrm{m} 1}-t_{\mathrm{m} 2}\right) /\left(w_{1}+w_{2}\right)$ where $w$ is the peak width; $N=5.54\left(t_{\mathrm{m}} / w_{1 / 2}\right)_{2}$ where $w_{1 / 2}$ is the peak width at half height.

${ }^{\mathrm{b}}$ Sample injection: electrokinetic $(-20 \mathrm{kV}, 20 \mathrm{~s})$ with nebulizer gas flow $\left(11 \mathrm{~min}^{-1}\right)$; applied voltage for the analysis is $-20 \mathrm{kV}$; background electrolyte buffers for the separation of $\mathrm{CrO}_{4}{ }^{2-}-\mathrm{Cr}^{3+}$ is phosphate $(20 \mathrm{mM}, \mathrm{pH} 6.5), \mathrm{HAsO}_{4}{ }^{2-}-\mathrm{Ph}_{4} \mathrm{As}^{+}$is pyromellitate (20 mM, pH 6.4), $\mathrm{SeO}_{4}{ }^{2-}-\mathrm{SeO}_{3}{ }^{2-}$ is acetate $(20 \mathrm{mM}, \mathrm{pH} 6.0)$.

${ }^{\mathrm{c}}$ Sample injection: electrokinetic $(+20 \mathrm{kV}, 20 \mathrm{~s})$ with nebulizer gas flow $\left(11 \mathrm{~min}^{-1}\right)$ (exception: no applied voltage for the $\mathrm{HAsO}_{4}{ }^{2-}-\mathrm{Ph}_{4} \mathrm{As}^{+} ;-20 \mathrm{kV}$ for $\mathrm{SeO}_{4}{ }^{2-}-\mathrm{SeO}_{3}{ }^{2-}$ ); applied voltage for the analysis is $+20 \mathrm{kV}$ (exception: $-20 \mathrm{kV}$ for the mixtures of $\mathrm{HAsO}_{4}{ }^{2-}-\mathrm{Ph}_{4} \mathrm{As}^{+}$and $\mathrm{SeO}_{4}{ }^{2-}-\mathrm{SeO}_{3}{ }^{2-}$ ); background electrolyte is phosphate buffer $(20 \mathrm{mM}, \mathrm{pH} 6.2)$.

With hydrodynamic injection but nebulizer gas flow off, a lower peak height for $(\mathrm{Ph})_{4} \mathrm{As}^{+}$and a greater amount of $\mathrm{SeO}_{4}{ }^{2-}, \mathrm{SeO}_{3}{ }^{2-}$ and $\mathrm{HAsO}_{4}{ }^{2-}$ was injected, and they were all detectable (Fig. 5C). The migration order was $(\mathrm{Ph})_{4} \mathrm{As}^{+}>\mathrm{HAsO}_{4}{ }^{2-}$, just the reverse of that observed in the bonded phase. A distinct evidence of different surface charge on bonded phase from that of the bare fused silica was shown. Changing the polarity of both sample injection and the separation applied voltage to $-20 \mathrm{kV}$ led to a well separated selenium species but no resolved arsenic species (Fig. 5D). Further, with the hydrodynamic injection at a nebulizer gas flow of $11 \mathrm{~min}^{-1}$, they were all well separated (Fig. 5E). However, the intensities of both chromium and selenium species were reduced significantly. In summary, the separation efficiencies of the CE-ICPMS analysis for chromium, arsenic and selenium species with various capillary columns were listed in Table 3. A slower migration velocity, a greater theoretical plate and a different polarity of the injection voltage clearly demonstrate different separation mechanisms. In the bonded phase, several predominant interaction forces including anion complexation, anion exchange and shape selectivity of the cavity might be considered.

\subsection{Linearity of calibration}

In order to evaluate the potential of the present method for quantitative uses, the linearity of the calibration lines were estimated by correlating the peak height to sample concentration. Comparison of the bonded phase with the bare fused silica showed that both linear range and detection limit were comparable (Table 4). Meanwhile they exhibited good linearity within the tested range.

\subsection{Analytical application}

${ }^{40} \mathrm{Ar}^{35} \mathrm{Cl}^{+}$presents a major problem in the measurement of ${ }^{75} \mathrm{As}^{+}$. The ${ }^{40} \mathrm{Ar}^{35} \mathrm{Cl}^{+}$peak is quite intense, and arsenic is monoisotopic, leaving no second-choice isotope. Thus, determination of As by ICPMS cannot be conducted in solutions containing chlorine species. Here a sample of $1 \mathrm{ppm}$ arsenate in

Table 4

Linearity of calibration and detection limits for the determination of metal speciation by CE/CEC-ICPMS with various capillary columns ${ }^{\mathrm{a}}$

\begin{tabular}{|c|c|c|c|c|c|c|c|c|c|c|}
\hline \multirow[t]{2}{*}{ Analyte } & \multicolumn{5}{|c|}{ [28] ane- $\mathrm{N}_{6} \mathrm{O}_{2}$ bonded phase } & \multicolumn{5}{|l|}{ Bare fused silica } \\
\hline & Range (ng ml ${ }^{-1}$ ) & Slope & Intercept & $r^{2}$ & $\mathrm{DL}\left(\mathrm{ng} \mathrm{ml}^{-1}\right)$ & Range (ng ml ${ }^{-1}$ ) & Slope & Intercept & $r^{2}$ & $\mathrm{DL}\left(\mathrm{ng} \mathrm{ml} \mathrm{l}^{-1}\right)$ \\
\hline $\mathrm{CrO}_{4}{ }^{2-}$ & $5-500$ & 68.4 & 400 & 0.9980 & 1 & $10-500$ & 43.6 & 2424 & 0.9974 & 3 \\
\hline $\mathrm{Cr}^{3+}$ & $5-500$ & 105 & 388 & 0.9970 & 1 & $10-500$ & 77.0 & 2693 & 0.9976 & 2 \\
\hline $\mathrm{HAsO}_{4}{ }^{2-}$ & $5-2000$ & 48.8 & 1675 & 0.9980 & 2 & $20-2000$ & 38.8 & 569 & 0.9960 & 10 \\
\hline$(\mathrm{Ph})_{4} \mathrm{As}^{+}$ & $5-2000$ & 48.5 & 1175 & 0.9985 & 2 & $20-2000$ & 14.5 & 39.7 & 0.9982 & 20 \\
\hline $\mathrm{SeO}_{4}{ }^{2-}$ & $50-2000$ & 4.78 & 709 & 0.9934 & 20 & $20-2000$ & 19.7 & 2853 & 0.9961 & 5 \\
\hline $\mathrm{SeO}_{3}{ }^{2-}$ & $50-2000$ & 1.75 & 685 & 0.9935 & 30 & $20-2000$ & 10.8 & 2281 & 0.9950 & 8 \\
\hline
\end{tabular}

${ }^{\text {a }}$ Experimental conditions as in Table 3. 


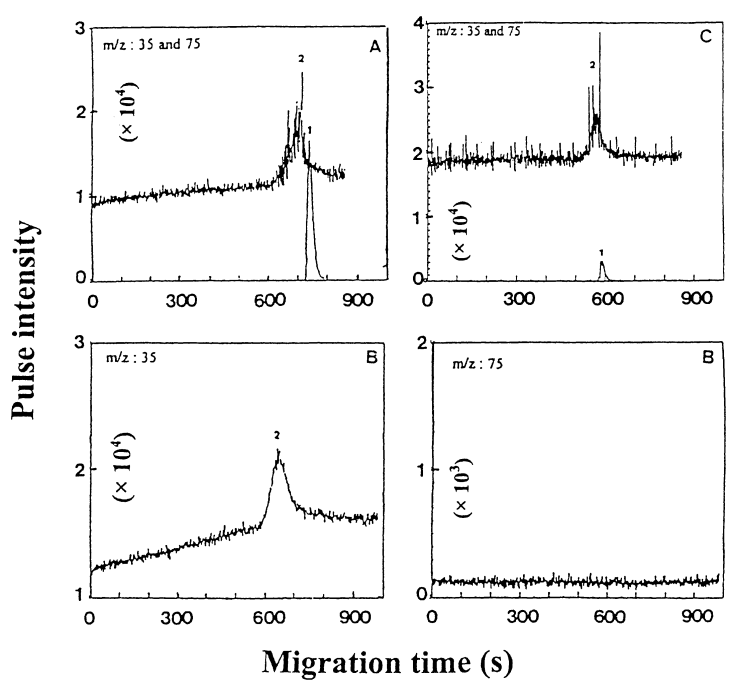

Fig. 6. Matrix effect for the determination of arsenic species. Capillary column: dimension is $160 \mathrm{~cm} \times 100 \mu \mathrm{m}$ i.d. (A and B) [28] ane- $\mathrm{N}_{6} \mathrm{O}_{2}$ bonded phase; (C) bare fused silica. Sample injection: electrokinetic method $(-20 \mathrm{kV}, 20 \mathrm{~s})$ with the nebulizer gas flow at $11 \mathrm{~min}^{-1}$. Separation voltage: $-20 \mathrm{kV}$. Background electrolyte: phosphate buffer $(20 \mathrm{mM}, \mathrm{pH}$ 6.2). Sample concentration: (A and $\mathrm{C}$ ) arsenate $\left(1 \mu \mathrm{g} \mathrm{ml}^{-1}\right)$ in chloride ion matrix $\left(1000 \mu \mathrm{g} \mathrm{ml}^{-1}\right)$; (B) chloride ion only $\left(1000 \mu \mathrm{g} \mathrm{ml}^{-1}\right)$. Peak identification: $1, \mathrm{HAsO}_{4}{ }^{2-} ; 2, \mathrm{Cl}^{-}$.

the presence of 1000 ppm chloride as an example was analyzed with the established system. The electropherogram (Fig. 6A) showed that $\mathrm{Cl}^{-}$moves faster than $\mathrm{HAsO}_{4}{ }^{2-}(\Delta t=39 \mathrm{~s})$ with a resolution of 0.77 . For further exploring the effect of $\mathrm{ArCl}^{+}$on the determination of ${ }^{75} \mathrm{As}$, we recorded simultaneously the signal of $m / z=35$ and 75 for introducing $1000 \mathrm{ppm}$ chloride sample. May be only a small amount of $\mathrm{ArCl}^{+}$produced, so that no significant peak intensity was observed at $m / z=75$ (Fig. 6B). When a bare fused silica capillary column was used, no resolution between $\mathrm{ArCl}^{+}$and $\mathrm{Cl}^{-}$was observed (Fig. 6C). Meanwhile, analyte signal suppression was five times greater than that demonstrated by the bonded phase. This was probable due to the higher selectivity of the bonded phase toward the anions than the bare fused silica $[3,4]$. The results showed that a sample with appropriate chloride content could be determined by the established CEC-ICPMS method. However, a real application of the proposed method is needed.

\section{Conclusion}

This preliminary study demonstrates the promise of using a simple device, a $\mathrm{Y}$ union tube as the CE/CEC-ICPMS interface. Following complete system optimization, both bonded phase and bare fused silica capillary columns could be used for the chromium, arsenic and selenium speciation study. The limits of detection, defined as three times the standard deviation of seven blank water samples are in the low $\mathrm{ng} \mathrm{ml}^{-1}$ range. As to the linear range for these systems, two to three orders of magnitude can be normally achievable. Comparison of the results in this work with those by UV detection [3], or CE-ICPMS by Mei et al. [8] and Olesik et al. [5], showed that the established method offers both a simple and highly sensitive method for the speciation study. Meanwhile, the bonded phase seems more appropriate for the complicated matrix sample, since the separation mechanism might be based on anion complexation. Moreover, sample with higher chloride content than the tested value, dilution must be made before the analysis. Furthermore, a farther away of the Pt electrode to the nebulizer makes the plasma not easy to extinguish. For improving the separation efficiency, a microconcentric nebulizer will be used instead of the cross-flow nebulizer. This work is now in progress.

\section{Acknowledgements}

The authors thank the National Science Council of Taiwan for financial support.

\section{References}

[1] M.G. Cikalo, K.D. Bartle, M.M. Robson, P. Myers, M.R. Euerby, Analyst 123 (1998) 87R.

[2] J.C. Hsu, W.H. Chen, C.Y. Liu, Analyst 122 (1997) 1393

[3] C.Y. Liu, W.H. Chen, J. Chromatogr. A. 815 (1998) 251.

[4] W.H. Chen, C.Y. Liu, J. Chromatogr. A 848 (1999) 401.

[5] J.W. Olesik, J.A. Kinzer, S.V. Olesik, Anal. Chem. 67 (1995) 1 .

[6] Q. Lu, S.M. Bird, R.M. Barnes, Anal. Chem. 67 (1995) 2949.

[7] B. Michalke, P. Schramel, Fresenius' J. Anal. Chem. 357 (1997) 594.

[8] E. Mei, H. Ichihashi, W. Gu, S. Yamasaki, Anal. Chem. 69 (1997) 2187.

[9] Y. Lui, V. Lopez-Avila, J.J. Zhu, D.R. Wiederin, W.F. Beckert, Anal. Chem. 67 (1995) 2020. 
[10] Q. Lu, R.M. Barnes, Microchem. J. 54 (1996) 129.

[11] J.A. Kinzer, J.W. Olesik, S.V. Olesik, Anal. Chem. 68 (1996) 3250.

[12] M.A. Tarr, G. Zhu, R.F. Browner, Anal. Chem. 65 (1993) 1689.

[13] P.W. Kirlew, J.A. Caruso, Appl. Spectrom. 52 (1998) 770.

[14] S. Londesborough, J. Mattusch, R. Wennrich, Fresenius' J. Anal. Chem. 363 (1999) 577.

[15] G.E.M. Hall, J.C. Pelchat, G. Gauthier, J. Anal. At. Spectrom. 14 (1999) 205.

[16] A.M. de Bettencourt, M.F. Duarte, S. Facchetti, M.H. Florencio, M.L. Gomes, H.A. van't Klooster, L. Montanarella, R. Ritsema, L.F. Vilas-Boas, Appl. Organomet. Chem. 11 (1997) 439.

[17] J.F. Tyson, J. Anal. At. Spectrom. 14 (1999) 169.

[18] D. Kuehnelt, W. Goessler, K.J. Irgolic, Appl. Organomet. Chem. 11 (1997) 289.

[19] J.M.G. Lafuente, M.L.F. Sanchez, A. Sanz-Medel, J. Anal. At. Spectrom. 11 (1996) 1163.

[20] S.M. Bird, P.C. Uden, J.F. Tyson, E. Block, E. Denoyer, J. Anal. At. Spectrom. 12 (1997) 785.
[21] F. Li, W. Goessler, K.J. Irgolic, J. Chromatogr. A 830 (1999) 337.

[22] G. Alsing Pedersen, E.H. Larsen, Fresenius' J. Anal. Chem. 358 (1997) 591.

[23] K.G. Heumann, S.M. Gallus, G. Radlinger, J. Vogl, Spectrochim. Acta. B 53B (1998) 273.

[24] T. Guerin, A. Astruc, M. Astruc, A. Batel, M. Borsier, J. Chromatogr. Sci. 35 (1997) 213.

[25] B. Michalke, P. Schramel, J. Chromatogr. A 807 (1998) 71.

[26] B. Michalke, P. Schramel, Electrophoresis 19 (1998) 270.

[27] R.C. Richter, K. Swami, S. Chace, L. Husain, Fresenius' J. Anal. Chem. 361 (1998) 168.

[28] J.A. Kinzer, J.W. Olesik, S.V. Olesik, Anal. Chem. 68 (1996) 3250.

[29] V. Majidi, N.J. Miller-Ihli, Analyst 123 (1998) 803.

[30] J.A. Dean, Lange's Handbook of Chemistry, McGraw-Hill, New York, 1985.

[31] R.C. Weast, Handbook of Chemistry and Physics, 66th Edition, CRC Press, Boca Raton, FL, 1985, p. D-168. 